\title{
Prioritizing Service Supply-Chain Performance Measures Using Multi-Criteria Decision-Making Methodologies
}

\author{
Haidar ABBAS ${ }^{1}$, Alamir Al ALAWI ${ }^{2}$, Khadija Al MAKTOUMI ${ }^{3}$ \\ Received: August 01, 2020 Revised: October 05, 2020 Accepted: October 15, 2020
}

\begin{abstract}
This study focuses on identifying and prioritizing the broader performance measures for the service supply chains by taking the case of Majan Electricity Company, Sohar, in the Sultanate of Oman. For an examination of the uniformity of ultimate objectives and the priorities therein, two strata of respondents with a total of fourteen respondents were approached for their valuable insights. Suitable structured instruments were personally administered to elicit the insightful and worthy responses. The two multi-criteria decision-making techniques, namely, the Fuzzy Analytical Hierarchy Process and the Best-Worst Method were used to reach a meaningful prioritization of the identified and refined broader performance measurement dimensions. The results show that there exists a minor gap between the two respondents' groups in terms of their prioritizations. The major finding points to the difference in terms of the topmost priorities as revealed by the two set of respondents. For one group of respondents, the customer satisfaction matters the most, whereas for the other group, it is the overall profitability that matters the most. This gap against the utopian state assists in concluding that there is a requirement to reorient the employees so as to have a shared and common understanding of the organizational priorities.
\end{abstract}

Keywords: Service Supply Chains, Performance Measurement, Best-Worst Method, Fuzzy Analytical Hierarchy Process, Multi Criteria Decision Making

JEL Classification Code: M00, M10, M11, M31

\section{Introduction}

Extreme level of competition and ever-heightened customer expectations have led to the emergence of supplychain management and modern logistics infrastructure as a mean of competitive advantage. Optimization of overall costs, elimination of resource wastage (production or process),

${ }^{1}$ First Author and Corresponding Author. Assistant Professor, Department of Business Administration, College of Applied Sciences, University of Technology \& Applied Sciences, Salalah, Sultanate of Oman [Postal Address: P.O. Box 347, PC 215, Sa'ada, Salalah, Sultanate of Oman] Email: haidar.sal@cas.edu.om

${ }^{2}$ Assistant Dean, College of Applied Sciences, University of Technology \& Applied Sciences, Salalah, Sultanate of Oman.

Email: alamir.sal@cas.edu.om

${ }^{3}$ Department of Human Resources, Majan Electricity Company, Sohar, Sultanate of Oman.

Email: Khadijah.AlMaktoumi@majanco.nama.om

(c) Copyright: The Author(s)

This is an Open Access article distributed under the terms of the Creative Commons Attribution Non-Commercial License (https://creativecommons.org/licenses/by-nc/4.0/) which permits unrestricted non-commercial use, distribution, and reproduction in any medium, provided the original work is properly cited. enhanced flexibility, more variety, operational integration, outsourcing trends, and adoption of the e-commerce, have further paved the ground for the development of the supply-chain management approach (Stevenson, 2002). The manufacturing sector drew the maximum focus of researchers, whereas the service sector could engage the researchers' efforts only around 1990s (Sengupta et al., 2006; Ming et al., 2009; Zhang \& Chen, 2015). However, the service supply chains resemble their counterparts (manufacturing supply chains) in their dealings and transactions with their upstream suppliers, downstream customers, and performance of certain functions by themselves or through outsourcing mode (Ming et al., 2009). Nevertheless, a service supply chain is handicapped in operating without an auxiliary physical supply chain. The intensity of labor (Sengupta et al., 2006), involvement of customer during the service creation and degree of homogeneity (Ellram et al., 2004), intangibility, simultaneity of production and consumption, and customersupplier duality (Sampson, 2000) largely distinguish between a manufacturing and a service supply chain. A service supply chain (SSC) is defined as "an integrated management of service information, service processes, service capacity, 
service performance and service funds from the earliest suppliers to the ultimate customers" (Ellram et al., 2004).

Broadly speaking, the sustenance, excellence or failure of supply chains is the major concern for all the stakeholders involved, which is determined by the certain performance indicators, performance matrixes or models. For instance, the Supply Chain Operations Reference (SCOR) focuses on five dimensions - plan, source, make, deliver, and return - whereas, the Balance Score Card concentrates on four different perspectives - financial, customer, internal business process, and innovation and learning (Taticchi et al., 2010). Hence, identification of the right performance parameters in a given context and then prioritizing them rationally becomes an issue of prime importance. The clarity about what is more important than the rest, and how the various performance dimensions have to be trade-offed in order to optimize the overall performance of service supply chains, guides one and all throughout their individual and group endeavors.

Given the importance of the right kind of prioritization among the various performance parameters, this research aims to prioritize the broader performance parameters of the service supply chain in the context of Majan Electricity Company (MJEC). For the purpose of bringing more substantiated and comparative outcomes, it uses the two multi-criteria decision-making approaches, namely, the Fuzzy Analytical Hierarchy Process (AHP) and the BestWorst Method (BWM). Majan Electricity Company (MJEC), being a closely-held Joint Stock company in the Sultanate of Oman, is listed under the Omani Commercial Companies Law. It became functional on May 1st, 2005. Having been licensed by the Authority for Electricity Regulation, Oman, it deals in the regulated distribution of electricity in three governorates, namely, North Batinah, Al Dhahirah and Al Buraimi.

\section{Literature Review}

The emergence of supply chain management and modern logistics infrastructure as a means of competitive advantage couldn't draw the focus of supply chain researchers towards service supply chains until 1990s (Sengupta et al., 2006; Zhou et al., 2009; Zhang \& Chen, 2015).

Mounting competitive pressure and dynamic business environment have oriented the supply chains to evaluate themselves not only on financial measures, but also on various non-financial measures such as customer satisfaction, sustainability and resilience (Tripathi \& Gupta, 2019). In order to satiate the customers' various requirements, the supply chains focus on their extended (performance) activities, namely, on-time delivery, product availability, an optimum level of inventory, and responsiveness.

Over the time, the researchers have proposed various performance measures and models. For instance, the Supply
Chain Operations Reference (SCOR) model offers five elements, namely, plan, source, make, deliver, and return, whereas, the Balance Score Card provides four different perspectives, namely, financial, customer, internal business process, and innovation and learning (Taticchi, et al.2010; Kaplan \& Norton, 2001). The balanced scorecard was extended by other researchers (Brewer \& Speh, 2001) who attached particular goals to each of these perspectives. The profit margin, flow of cash, growth of revenue, and returnon-assets with their specific measures related to financial perspective, whereas the product and services as viewed by the customers, timeliness, flexibility and customer values, and their measures related to the customer perspective. The reduction in waste, reduction in time, flexibility in response, and cost reduction per unit and their measures related to internal business process perspective, whereas the innovation related to product as well as process, proper management of partnership(s), flows of relevant information and their related measures are related to the learning and growth perspective. The SERVQUAL was extended to fit the educational supply chain (Lee \& Seong, 2020).

Operating performance, earnings and profitability, financial structure, growth, asset quality, and liquidity were considered to assess the business sustainability performance of Taiwanese banks using multi-criteria decision-making. These five broader dimensions were taken into consideration along with their related 18 sub-dimensions (Abbaspour, 2019). An extensive review of the various performance measures particularly in the context of service sector was done. Afterwards, the researchers (Santos \& Leite, 2016) used Analytical Hierarchy Process (AHP) to prioritize the various processes and metrics. The processes, namely, source, plan, deliver, make, and return are arranged in order of importance. The most important matrices include perfect order fulfillment, stock cost, average answer time to a service request, deliveries carried out without failures, and customer complaint.

Six metrics, namely, web-enabled service, data reliability, time and cost, e-response, invoice presentation and payment, and e-document management metrics, and 21 measures were developed by Sambasivan et al. (2009), while studying the performance measures and metrics for e-supply chains. However, their overall perspective was limited to the benefits, and the evidences were solely collected from the companies in the electronic industry.

The eight dimensions of service performance were used to measure the tourism supply chain management performance (Palang \& Tippayawong, 2019). These include the order process management, supplier relationship management, service performance management, capacity and resources management, customer relationship management, demand management, information and technology management, and tour finance supply chain. Among these selected parameters of performance, order process management, 
Haidar ABBAS, Alamir Al ALAWI, Khadija Al MAKTOUMI /

service performance measurement and supplier relationship management emerged as first, second and third in terms of significance.

Three measures of supply-chain performance, namely, resource measures, customer responsiveness measures, and flexibility measures were also developed (Beamon, 1999). While studying the performance measurement of reverse supply chains, six perspectives were considered, namely, citizenship and legislation, financial, stakeholder, process, innovations and growth, and flexibility (Butzer et al., 2017). A service performance measurement framework in the context of hoteling industry was also developed by researchers using the Extent Fuzzy Analytical Hierarchy Process (Cho et al., 2012). This measurement framework covers three major assessment areas, namely, service supply chain operations (responsiveness, flexibility and reliability), customer service (tangibles, assurance and empathy), and corporate management (profitability, cost, and asset and resource utilization) with a total of 29 measures. Another study used five broader attributes of supply chain performance, namely, reliability (perfect order fulfillment), responsiveness (order fulfillment cycle time), agility (upside supply chain flexibility, upside supply chain adaptability, downside supply chain adaptability and overall value at risk), cost (total cost to serve), and asset management efficiency (cash-to-cash cycle time, return on supply chain fixed assets, return on working capital) (Lin \& Chang, 2019).

To sum up the whole discourse, one may say that in different contexts, researchers have used different methodologies as well as specific performance dimension to achieve their respective research objectives. For instance, the performance measures and metrics for e-supply chains (Sambasivan et al., 2009) differ to a significant extent from the ones used in the context of the textile industry (Shujaat et al., 2019), hotel industry (Cho et al., 2012) or banking industry (Santos \& Leite, 2016). Thus, identifying the right performance parameters in a given context, prioritizing them rationally and ensuring that all the value-adding agents are on the same page with respect to them becomes an issue of prime importance. Hence, after this thorough literature review, the researchers initially extracted 15 dimensions and sub-dimensions of service supply chain performance measurement. Later, as advised by the practitioners from Majan Electricity Company, these 15 dimensions were reduced to six broader and most significant performance measurement dimensions. For the purpose of bringing more substantiated and comparative outcomes, we use the two multi-criteria decision-making approaches.

\section{Research Methodology}

Generally, the research methodology is regarded as the backbone of a research. This research uses a qualitative approach to identify and prioritize the various measures of service supply chain in the context of Majan Electricity Company. For this purpose, the researchers have used the Fuzzy Analytical Hierarchy Process (FAHP) and the BestWorst Method (BWM). Scholars (Xu et al., 2020; Moslem et al., 2019; Ghorbanzadeh et al., 2019; Diouf \& Kwak, 2018, Mou et al., 2018) have been constantly trying to use these methods in different combinations so as to suit the context of their study objectives. Two structured questionnaires were developed; one for each type of techniques. This helped the researchers to examine whether all the employees have the same shared understanding of these selected performance parameters. The one for Fuzzy Analytical Hierarchy Process (FAHP) was personally administered to a total of eight respondents, whereas the questionnaire for the BestWorst Method (BWM) was administered to six respondents. As these selected performance parameters are broader parameters, which are usually comprised of more than one sub-parameter, the researchers ensured that the respondent is informed about each of these indicators before he/she responds. All the respondents were holding the same ranks across different units of the company.

\subsection{Fuzzy Analytical Hierarchy Process (FAHP)}

After a comprehensive and rigorous review of relevant research papers, the researchers identified more than 15 dimensions related to the performance of service supply chains. However, based on experts' opinion, the following six most significant broader performance parameters have been examined using the Fuzzy Analytical Hierarchy Process (FAHP) and the Best-Worst Method (BWM) for the purpose of prioritization.

1) Cost efficiency (Santos \& Leite, 2016; Sambasivan et al., 2009; Beamon, 1999; Lin \& Chang, 2019; Giannakis et al., 2009; Jayaram \& Xu, 2016, Wang et al., 2015): it refers to how cost-effective an enterprise is in producing its output and serving its customers.

2) Profitability (Abbaspour, 2019; Cho et al., 2012): it is the capability of a business to offer its owner some amount of money when all the costs have been deducted from total revenues.

3) Responsiveness (Beamon, 1999; Lin \& Chang, 2019; Adivar et al., 2019): it is reflected in terms of how instantly the customer requests and/or complaints are addressed.

4) Empathy (Santos \& Leite, 2016): it is degree to which an enterprise tries to understand and consider a problem from the perspective of one who is actually facing it.

5) Supplier/buyer relationship (Palang \& Tippayawong, 2019; Nugraha \& Hakimah, 2019): it indicates the efforts made by the company to make and maintain healthy and mutually beneficial relationships with its suppliers as well as customers. 
6) Customer satisfaction (Tripathi \& Gupta, 2019): it refers to the degree to which customer is happy with what he gets in relation to his expectations.

A seven-step process to implement FAHP (Ahyan, 2013) includes: a) choosing and pairwise comparison of

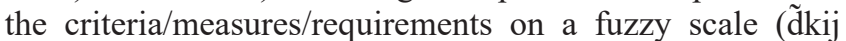
indicates the kth decision maker's preference of ith criterion over jth criterion) to make a pairwise contribution matrix $\left(\tilde{\mathrm{A}}^{\mathrm{k}}\right)$, b) taking the average of comparison ( $\tilde{\mathrm{d}}_{\mathrm{ij}}$ ) in case of more than one decision maker, c) using this average comparison to update the pairwise contribution matrix $(\tilde{\mathrm{A}})$, d) calculating the geometric mean of the fuzzy comparison values $\left(\tilde{\mathrm{r}}_{\mathrm{i}}\right)$ for each criterion, e) obtaining the fuzzy weights for each criterion $\left(\tilde{\mathrm{w}}_{\mathrm{i}}\right)$ by first taking the vector summation of each $\tilde{r}_{i}$, then finding the inverse of the summation vector, then arranging these inverse values in ascending order and finally, by taking the product of each $\tilde{r}_{i}$ with its reverse factor arranged in ascended order, f) de-fuzzifying these fuzzy weights using center of area method where defuzzified value $\left(\mathrm{M}_{\mathrm{i}}\right)$ is an average of the fuzzy triangular values, and g) obtaining the normalized weights $\left(\mathrm{N}_{\mathrm{i}}\right)$ after dividing each of these defuzzified weights $\left(\mathrm{M}_{\mathrm{i}}\right)$ by the summation $\left(\sum \mathrm{M}_{\mathrm{i}}\right)$.

Most similar studies are reported to have used the geometric mean method for the consolidation of many individual experts' preferences (Abbas, 2018). Based on these normalized scores, the various criteria are ranked.

\subsection{Best-Worst Method (BWM)}

Secondly, the objective of this research has been worked out using Best-Worst Method (BWM) as follows (Rezaei, 2015).

The identified criteria, here, are not different from the ones used for Fuzzy Analytical Hierarchy Process (FAHP). The same performance parameters were used to achieve the study objective with a different set of respondents, but with the same ranks.

Determination of the best and worst criteria: every respondent is expected to make its own selection, which may or may not be same for all in terms of the best and the worst.

Determination of the preference of the best measure (criterion) vis-a-vis all other measures (criteria): usually, researchers use a scale of 1 to 9 . The same has been adopted in this study as well. A score of 1 signifies equal importance of the best measure (criterion) in relation to the other measure (criterion), whereas a score of 9 means that the most important measure (criterion) is the most preferred in relation to the other measure (criterion). All the respondents provided their responses in separate questionnaire and, hence, the researchers had as many responses as the number of respondents.

Determination of the preference of all measures (criteria) in relation to the worst measure (criterion): in general, it is also done on the same 1 to 9 points scale, where a score of 1 means that the other criteria is as important as the worst one. However, a score of 9 means that the selected criterion is more important than the worst criterion. Again, the researchers received as many responses as the number of respondents.

Determination of the optimal weights using the linear model of Best-Worst Method (BWM), which averts the chances of obtaining multiple optimal results; the importance/preference ratings were collected from six respondents so as to reach a better opinion. In fact, based on each of these responses, there is a total of six different weights (one per respondent). The arithmetic mean is used to arrive at a single weight.

Consistency check: here, the researchers have to examine the degree of consistency among the results by means of comparing the value of Ksi with Zero (0). The closer is it to zero, the better is it from the reliability point of view (Nispeling, 2015).

\section{Results}

This section contains two sub-sections: the Analysis using Fuzzy Analytical Hierarchy Process (FAHP) and the Analysis using Best-Worst Method (BWM).

\subsection{Analysis using Fuzzy Analytical Hierarchy Process (FAHP)}

Firstly, the objective of this research has been worked out using Fuzzy Analytical Hierarchy Process (FAHP) as explained in the previous section.

For finding out the various individual ranks for these criteria, geometric means of all fuzzy set values (Table 1) is calculated to develop a consolidated matrix (Table 2). For the sake of brevity as well as to adhere to convention related to the FAHP result presentation, the individual responses used to arrive at the consensus have not been shown separately. The priorities for individual criterion (dimensions) are calculated using the geometric mean approach, weighing approach, defuzzification and normalization approach (Table 3). The higher the value of normalized weight $\left(\mathrm{N}_{\mathrm{i}}\right)$, the higher the rank. Customer satisfaction was found to have the highest priority whereas reliability as the lowest one.

As evident in Table 3., the customer satisfaction emerged with highest normalized score whereas reliability scored lowest. Thus, they were awarded first and the sixth ranks respectively.

\subsection{Analysis using Best-Worst Method (BWM)}

Following the procedure discussed previously, the collected responses from a group of respondents were analyzed. 
Table 1: Comparison Matrix For Criteria

\begin{tabular}{|c|c|c|c|c|c|c|}
\hline & $\begin{array}{l}\text { Customer } \\
\text { Satisfaction }\end{array}$ & Empathy & Reliability & Profitability & Responsiveness & $\begin{array}{c}\text { Cost } \\
\text { Efficiency }\end{array}$ \\
\hline $\begin{array}{l}\text { Customer } \\
\text { Satisfaction }\end{array}$ & $(1,1,1)$ & $(7,8,9)$ & $(6,7,8)$ & $(6,7,8)$ & $(6,7,8)$ & $(5,6,7)$ \\
\hline Empathy & $\begin{array}{c}(0.111 \\
0.125,0.143)\end{array}$ & $(1,1,1)$ & $(3,4,5)$ & $\begin{array}{c}(0.2 \\
0.25,0.333)\end{array}$ & $(1,2,3)$ & $\begin{array}{c}(0.125,0.143, \\
0.166)\end{array}$ \\
\hline Reliability & $\begin{array}{c}(0.125,0.143 \\
0.166)\end{array}$ & $\begin{array}{c}(0.2, \\
0.25,0.333)\end{array}$ & $(1,1,1)$ & $\begin{array}{c}(0.143,0.166 \\
0.2)\end{array}$ & $\begin{array}{c}(0.125,0.143 \\
0.166)\end{array}$ & $\begin{array}{c}(0.166,0.2 \\
0.25)\end{array}$ \\
\hline Profitability & $\begin{array}{c}(0.125,0.143 \\
0.166)\end{array}$ & $(3,4,5)$ & $(5,6,7)$ & $(1,1,1)$ & $(7,8,9)$ & $(6,7,8)$ \\
\hline Responsiveness & $\begin{array}{c}(0.125,0.143 \\
0.166)\end{array}$ & $(0.333,0.5,1)$ & $(6,7,8)$ & $\begin{array}{c}(0.111 \\
0.125,0.143)\end{array}$ & $(1,1,1)$ & $(4,5,6)$ \\
\hline Cost Efficiency & $\begin{array}{c}(0.125,0.143 \\
0.166)\end{array}$ & $(6,7,8)$ & $(4,5,6)$ & $\begin{array}{c}(0.125,0.143 \\
0.166)\end{array}$ & $(0.166,0.2,0.25)$ & $(1,1,1)$ \\
\hline
\end{tabular}

Table 2: Geometric means of fuzzy comparison values

\begin{tabular}{|l|c|c|c|}
\hline Dimensions & \multicolumn{3}{|c|}{ Ri } \\
\hline Customer Satisfaction & 4.430169 & 5.043777 & 5.642026 \\
\hline Empathy & 0.450192 & 0.573957 & 0.699855 \\
\hline Reliability & 0.204982 & 0.235302 & 0.2773 \\
\hline Profitability & 2.07034 & 2.402274 & 2.734753 \\
\hline Responsiveness & 0.692085 & 0.823912 & 1.021992 \\
\hline Cost Efficiency & 0.62954 & 0.723261 & 0.831571 \\
\hline Summation & 8.477308 & 9.802483 & 11.2075 \\
\hline Inverse Values & 0.117962 & 0.102015 & 0.089226 \\
\hline $\begin{array}{l}\text { Ascending Order of Inverse } \\
\text { Values }\end{array}$ & 0.089226 & 0.102015 & 0.117962 \\
\hline
\end{tabular}

Table 3: Prioritization and Ranking

\begin{tabular}{|l|c|c|c|c|c|c|}
\hline $\begin{array}{l}\text { Performance } \\
\text { Dimensions }\end{array}$ & \multicolumn{3}{|c|}{ Wi } & Mi & Ni & Rank \\
\hline $\begin{array}{l}\text { Customer } \\
\text { Satisfaction }\end{array}$ & 0.395286 & 0.514541 & 0.665545 & 0.525124 & 0.511741 & 1 \\
\hline Empathy & 0.040169 & 0.058552 & 0.082556 & 0.060426 & 0.058886 & 5 \\
\hline Reliability & 0.01829 & 0.024004 & 0.032711 & 0.025002 & 0.024364 & 6 \\
\hline Profitability & 0.184728 & 0.245068 & 0.322597 & 0.250798 & 0.244406 & 2 \\
\hline Responsiveness & 0.061752 & 0.084051 & 0.120556 & 0.088787 & 0.086524 & 3 \\
\hline Cost Efficiency & 0.056171 & 0.073783 & 0.098094 & 0.076016 & 0.074079 & 4 \\
\hline \multicolumn{7}{|c|}{$\Sigma \mathrm{Mi}$} \\
\hline
\end{tabular}


These weights may be seen in Table 4 and the measure of consistency is shown in Table 5. In the light of these results, one may say that among the selected dimensions, profitability and the reliability, are the most important and least important dimensions of performance measurement.
Figure 1 shows the results obtained after analyzing the responses of the two sets of respondents using Multi-Criteria Decision Making Techniques viz. Fuzzy Analytical Hierarchy Process (AHP) and Best-Worst Method (BWM).

Table 4: Optimal Weights for Criteria Set

\begin{tabular}{|l|c|c|c|c|c|c|}
\hline Weight & $\begin{array}{c}\text { Customer } \\
\text { Satisfaction }\end{array}$ & Empathy & Reliability & Profitability & Responsiveness & Cost Efficiency \\
\hline Respondent-I & 0.26051188 & 0.086837 & 0.0365631 & 0.4250457 & 0.104204753 & 0.086837 \\
\hline Respondent-II & 0.24021674 & 0.068633 & 0.0354004 & 0.39951836 & 0.160144491 & 0.096087 \\
\hline Respondent-III & 0.22936893 & 0.033981 & 0.065534 & 0.36529126 & 0.229368932 & 0.076456 \\
\hline Respondent-IV & 0.4052362 & 0.031873 & 0.0654525 & 0.2618099 & 0.130904952 & 0.104724 \\
\hline Respondent-V & 0.25606469 & 0.102426 & 0.0359389 & 0.41778976 & 0.102425876 & 0.085355 \\
\hline Respondent-VI & 0.27674701 & 0.069187 & 0.0374545 & 0.44529218 & 0.092249003 & 0.079071 \\
\hline Composite Score & 0.27802424 & 0.065489 & 0.0460572 & 0.38579119 & 0.136549668 & 0.088088 \\
\hline Ranks & 2 & 5 & 6 & 1 & 3 & 4 \\
\hline
\end{tabular}

Table 5: Optimal Weights for Criteria Set

\begin{tabular}{|l|l|}
\hline Weight & Ksi \\
\hline Respondent-I & 0.095978062 \\
\hline Respondent-II & 0.080915111 \\
\hline Respondent-III & 0.093446602 \\
\hline Respondent-IV & 0.118383608 \\
\hline Respondent-V & 0.094339623 \\
\hline Respondent-VI & 0.108201838 \\
\hline Composite Score & 0.098544141 \\
\hline
\end{tabular}
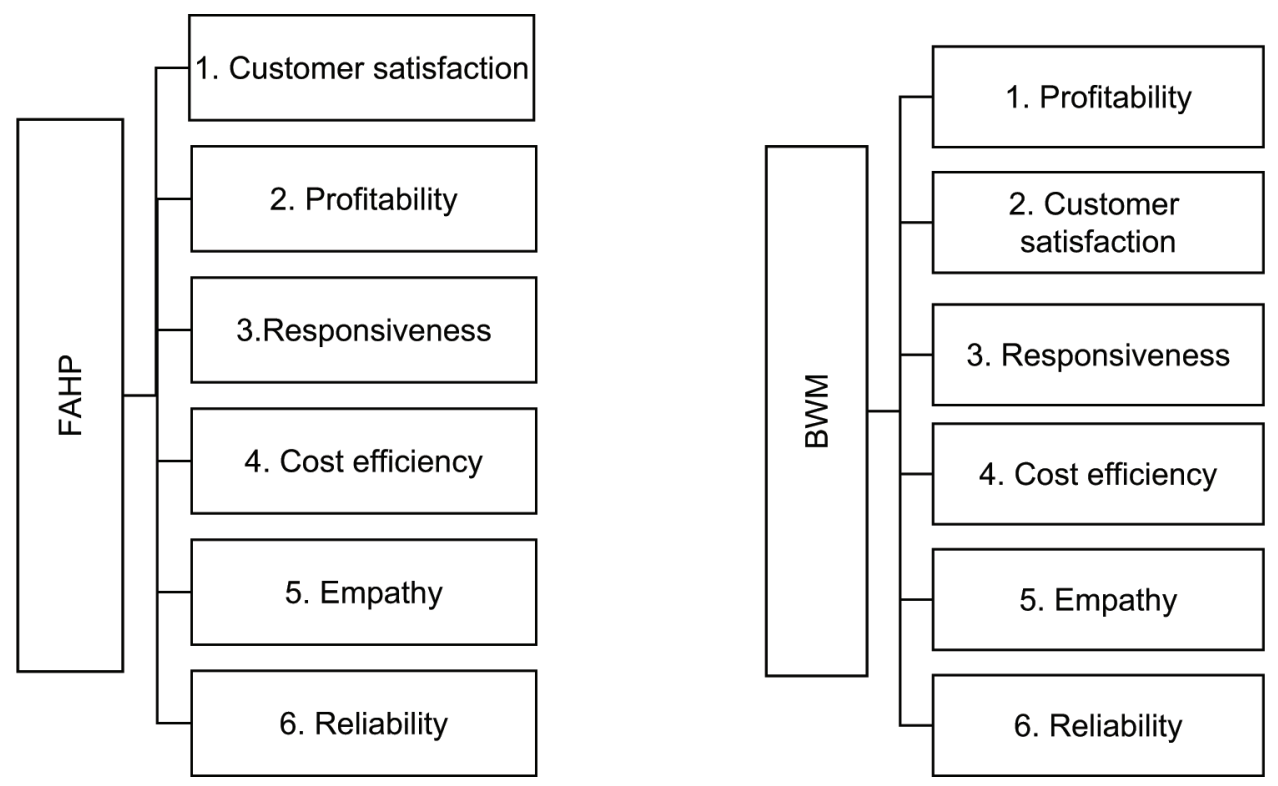

Figure 1: Illustration of the outcomes of Comparative Analysis 
Haidar ABBAS, Alamir Al ALAWI, Khadija Al MAKTOUMI /

\section{Discussion}

The results of Fuzzy Analytical Hierarchy Process (FAHP) establish that customers' satisfaction seems most important to the company, followed by profitability, responsiveness, cost efficiency, empathy, and reliability, respectively. Generally, it has been observed that it is the customer's satisfaction that drives everything in a company, and it is customer's dissonance, which drives everything out of a company (Kotler \& Armstrong, 2010). Hence, customers' satisfaction holds the topmost priority.

It is quite natural to understand that it is the contentment of the target market, which determines almost everything related to the fate of products and services. This is somehow in line with the findings of previous researchers (Wen, 2015) who established "the fulfillment of the promise made to shippers" in the service effectiveness facet as most important performance measure. Nevertheless, the profitability has also been one of the key objectives of the firms, which is non-existent particularly in the long run if the customers are not having a positive attitude towards a service/product. Naturally, the good relations with the stakeholders develop customer loyalty and suppliers' engagement at its best, while simmering down some occasional silly experiences at the least. Good relations with the customers convince and, at times, bound one to care about the welfare as well as agony of customers better than in normal circumstances. However, these findings differ from another study by Saleheen et al. (2018) who gave the topmost priority to the supplier relationship management in the context of manufacturing sector. Consequently, the service providers/employees are expected to be relatively more responsive. Their enhanced responsiveness is one of the major sources that yield cost efficiency.

As against it, the results of the Best-Worst Method (BWM) show that it is the profitability that matters the most for the supply chains in general, whereas the reliability still ranks the least important among the six measures (Figure 3). At the same time, it is noteworthy that, except for the mutation between the first two ranks, all other ranks remain the same. So, using FAHP, the researchers obtained an order of the performance parameters as (1) customer satisfaction, (2) profitability, (3) responsiveness, (4) cost efficiency, (5) empathy, and (6) reliability, whereas using the Best-Worst Method (BWM) it comes out as (1) profitability, (2) customer satisfaction, (3) responsiveness, (4) cost efficiency, (5) empathy, and (6) reliability. Obviously, it is the profitability, which drives the businesses and enterprises on the track of growth and development. Thus, preferring profitability to other measures is also a naturally-understood phenomenon. Logically, this profitability cannot be ensured without reaching out to the customers at a reasonable cost. Hence, the rank order of the other measures of performance also makes sense. One reason behind this apparent difference may be simply due to the difference of subjectivities. Individual holding the same or similar job profiles differ in terms of their judgments on account of their educational, social, cultural, economic, and demographic backgrounds. Otherwise also, the profitability and customer satisfaction go hand in hand. The profitability can only grow by increasing the number of customers, while ensuring a high retention rate. Thus, at the broader level, the two methods produced the same results, except for the first rank holder.

\section{Conclusions}

As illustrated and discussed at length in the previous two sections, the analysis results of the two datasets using two MCDM approaches, shows that one may say that, except for minor differences, the respondents expressed the uniformity of understanding, while mentioning their perceived priorities pertaining to the performance measures. Here, it is noteworthy to draw the attention of the management that following the shared vision of the company, all of the respondents should ideally be on exactly the same page, and there should not be any slightest difference in the priorities of these dimensions. Traditionally, accounting and finance people have been found more focused on optimizing the inflow and outflow of capital, whereas the marketing fellows are more focused on the service level. As academicians, researchers assume that this minor difference between the two strata of the respondents may have been due to their departmental affiliations and silo interests. In any case, the researchers feel a need of a thorough and in-depth followup study with more and different respondents, which could substantiate, improve or refute these findings. In case, the same or similar results are obtained again, management need to seriously take note of it and plan a reorientation of the employees.

Even, within the prioritization done based on the eight responses for FAHP and six responses for BWM, a low level of inconsistency among the responses is observed. Hence, future researchers may survey a larger number of respondents and carry out the follow-ups in case of inconsistencies. Future researchers may also incorporate the fuzzy set theory (Farajnejad \& Lau, 2017), use the fuzzy multicriteria decision-making models like fuzzy extent analysis method (Tong et al., 2020) or fuzzy analytical hierarchy process (Hoang \& Nguyen, 2020; Nguyen \& Nguyen, 2020). Furthermore, a comparative study may be conducted by taking more than one service firm vis-à-vis one or more manufacturing firm. In addition, a more comprehensive analysis of each of the parameters with their co-parameters and using these weights to selection the suppliers could be conducted. 


\section{References}

Abbas, H. (2018). Barriers to reverse logistics practices in pharmaceutical supply chains: an ISM approach. International Journal of Business Excellence, 16(1), 47-60.

Abbaspour, A. (2019). Supply chain analysis and improvement by using the SCOR model and Fuzzy AHP: A Case Study. International Journal of Industrial Engineering and Management Science, 6(2), 51-73.

Adivar, B., Hüseyinoğlu, I. Ö. Y., \& Christopher, M. (2019). A quantitative performance management framework for assessing omnichannel retail supply chains. Journal of Retailing and Consumer Services, 48, 257-269.

Ayhan, M. B. (2013). A fuzzy AHP approach for supplier selection problem: A case study in a Gear motor company. International Journal of Managing Value and Supply Chains, 4(3).11-23.

Beamon, B. M. (1999). Measuring supply chain performance. International Journal of Operations \& Production Management, 19(3), 275-292.

Brewer, P. C., \& Speh, T. W. (2001). Adapting the balanced scorecard to supply chain management. Supply Chain Management Review, 5(2), 48-56.

Butzer, S., Schötz, S., Petroschke, M., \& Steinhilper, R. (2017). Development of a performance measurement system for international reverse supply chains. Procedia Cirp, 61, 251-256.

Cho, D. W., Lee, Y. H., Ahn, S. H., \& Hwang, M. K. (2012). A framework for measuring the performance of service supply chain management. Computers \& Industrial Engineering, 62(3), 801-818.

Diouf, M., \& Kwak, C. (2018). Fuzzy AHP, DEA, and Managerial analysis for supplier selection and development; from the perspective of open innovation. Sustainability, 10(10), 3779.

Duleba, S., \& Moslem, S. (2018). Sustainable urban transport development with stakeholder participation, an AHP-kendall model: A case study for mersin. Sustainability, 10(10), 36-47.

Ellram, L. M, Tate, W.L., \& Billington, C. (2004). Understanding and Managing the Services Supply Chain. Journal of Supply Chain Management, 40(4), 17-32.

Farajnejad, E., \& Lau, W. Y. (2017). A Fuzzy Based Early Warning System to Predict Banking Distress on Selected Asia-Pacific Countries. Journal of Asian Finance, Economics and Business, 4(1), 39-49. http://dx.doi.org/10.13106/jafeb.2017.vol4.no1.39

Ghorbanzadeh, O., Moslem, S., Blaschke, T., \& Duleba, S. (2019). Sustainable urban transport planning considering different stakeholder groups by an interval-AHP decision support model. Sustainability, 11(1), 9.

Giannakis, M. (2011). Management of service supply chains with a service-oriented reference model: the case of management consulting. Supply Chain Management: An International Journal, 16(5), 346-361.

Hoang, L. K. \& Nguyen, K T. (2020). Fuzzy-AHP Application in Analyzing the Factors Affecting Quality of Rural Labor.
Journal of Asian Finance, Economics and Business, 7(8), 715721. https://doi.org/10.13106/jafeb.2020.vol7.no8.715

Jayaram, J., \& Xu, K. (2016). Determinants of quality and efficiency performance in service operations. International Journal of Operations \& Production Management, 36(3), 265-285.

Kaplan, R. S., \& Norton, D. P. (2001). Transforming the balanced scorecard from performance measurement to strategic management: Part I. Accounting Horizons, 15(1), 87-104.

Kotler, P., \& Armstrong, G. (2010). Principles of marketing. London, UK: Pearson education.

Lee, H. J., \& Seong, M. H. (2020). A Study on the Effects of Business Service Quality on Satisfaction, Commitment, Performance, and Loyalty at a Private University. Journal of Asian Finance, Economics and Business, 7(9), 439-453. https:// doi.org/10.13106/jafeb.2020.vol7.no9.439

Lin, A. J., \& Chang, H. Y. (2019). Business sustainability performance evaluation for Taiwanese banks-A hybrid multiple-criteria decision-making approach. Sustainability, 11(8), 2236.

Ming Z., Taeho P. \& John Y. (2009). Commonalities and differences between service and manufacturing supply chains: Combining operations management studies with supply chain management. California Journal of Operations Management, 7(1), 136-143.

Moslem, S., Ghorbanzadeh, O., Blaschke, T., \& Duleba, S. (2019). Analysing stakeholder consensus for a sustainable transport development decision by the fuzzy AHP and interval AHP. Sustainability, 11(12), 3271.

Mou, W., Wong, W. K., \& McAleer, M. (2018). Financial credit risk evaluation based on core enterprise supply chains. Sustainability, 10(10), 3699.

Nguyen, P. T., \& Nguyen, Q. L. H. T. T. (2020). Critical Factors Affecting Construction Price Index: An Integrated Fuzzy Logic and Analytical Hierarchy Process. Journal of Asian Finance, Economics and Business, 7(8), 197-204. https://doi. org/10.13106/jafeb.2020.vol7.no8.197

Nispeling, T. (2015). Multi-Criteria Supplier Selection in the Edible Oil Industry: The Case of a New Oils \& Fats Plant in China. Doctoral dissertation. Delft University of Technology, TU Delft.

Nugraha, A. T. \& Hakimah, Y. (2019). Role of Relational Capabilities on the Supply Chain Performance of Indonesian Textile Sector with Moderating Effect of Technology Adoption. International Journal of Supply Chain Management, 8(5), 509522.

Palang, D. \& Tippayawong, K.Y. (2019). Performance evaluation of tourism supply chain management: the case of Thailand. Business Process Management Journal, 25(6), 1193-1207.

Rezaei, J. (2015). Best-worst multi-criteria decision-making method. Omega, 53, 49-57.

Saaty, T. L., Peniwati, K., \& Shang, J. S. (2007). The analytic hierarchy process and human resource allocation: Half the story. Mathematical and Computer Modelling, 46(7-8), 1041-1053. 
Saleheen, F., Habib, M.M., \& Hanafi, Z. (2018). An Empirical Study on Supply Chain Management Performance Measurement through AHP. International Journal of Supply Chain Management, 7(6), 349-356.

Sambasivan, M., Mohamed, Z. A., \& Nandan, T. (2009). Performance measures and metrics for e-supply chains. Journal of Enterprise Information Management, 22(3), 346-360.

Sampson, S. E. (2000). Customer-Supplier Duality and Bidirectional Supply Chains in Service Organizations. International Journal of Service Industry, 11(4), 348-359.

Santos, T. F. D., \& Leite, M. S. A. (2016). Performance measurement system in supply chain management: application in the service sector. International Journal of Services and Operations Management, 23(3), 298-315.

Sengupta, K., Heiser, D. R. \& Cook, L. S. (2006). Manufacturing and Service Supply Chain Performance: A Comparative Analysis. Journal of Supply Chain Management, 42(4), 4-15.

Shujaat, M., Naghavi, N., \& Mubarak, F. (2019). Impact of supplier relational capital on supply chain performance in Pakistani textile industry. Asian Economics and Finance Review, 9(3), 318-328.

Stevenson, W.J. (2002). Operations Management (7th ed). New York, NY: McGraw-Hill.

Taticchi, P., Tonelli, F., \& Cagnazzo, L. (2010). Performance measurement and management: a literature review and a research agenda. Measuring Business Excellence, 14(1), 4-18.

Tong, K. H., Nguyen, Q. L. H. T. T., Nguyen, T. T. M., Nguyen, P. T., \& Vu, N. B. (2020). Applying the Fuzzy DecisionMaking Method for Program Evaluation and Management Policy of Vietnamese Higher Education. Journal of Asian Finance, Economics and Business, 7(9), 719-726. https://doi. org/10.13106/jafeb.2020.vol7.no9.719

Tripathi, S., \& Gupta, M. A (2019). Current Review of Supply Chain Performance Measurement Systems. In Advances in Industrial and Production Engineering (27-39). Singapore: Springer.

Wang, Y., Wallace, S. W., Shen, B., \& Choi, T. M. (2015). Service supply chain management: A review of operational models. European Journal of Operational Research, 247(3), 685-698.

Wen, Y-F. (2015). Evaluation of Supply Chain Performance for Shipping Industry by Using AHP Method. International Journal of Computer \& Mathematical Sciences, 4(10), 117-129.

Xu, J., Yu, L., \& Gupta, R. (2020). Evaluating the Performance of the Government Venture Capital Guiding Fund Using the Intuitionistic Fuzzy Analytic Hierarchy Process. Sustainability, 12(17), 6908.

Zhang, R.Q. \& Chen, H.Q. (2015). A Review of Service Supply Chain and Future Prospects. Journal of Service Science and Management, 8(4), 485-495. 